\title{
Government procurement: market access, transparency, and multilateral trade rules
}

\author{
Simon J. Evenett ${ }^{\mathrm{a}, \mathrm{b}}$, Bernard M. Hoekman ${ }^{\mathrm{b}, \mathrm{c}, *}$ \\ ${ }^{\text {a }}$ Said Business School, Oxford University, Park End Street, Oxford, OX1 1HP, UK \\ ${ }^{\mathrm{b}}$ CEPR, London, UK \\ ${ }^{\mathrm{c}}$ World Bank, 1818 H Street NW, Washington, DC 20433, USA
}

Received 18 November 2002; received in revised form 25 November 2003; accepted 7 January 2004

\begin{abstract}
This paper examines the effects on national welfare and market access of two public procurement practices, discrimination and nontransparency. Both policies have become prominent in international trade negotiations, including the Doha Round of World Trade Organization (WTO) trade talks. We show that fostering either domestic competition or transparency in state contracting tends to improve welfare. In contrast, we find no clear-cut effect on market access of ending discrimination or improving transparency. This mismatch between market access and welfare effects may account for the slower progress in negotiating procurement disciplines in trade agreements than for traditional border measures such as tariffs.

(C) 2004 Elsevier B.V. All rights reserved.

JEL classification: $\mathrm{F} 13 ; \mathrm{H} 57$

Keywords: Government procurement; WTO; Multilateral trade agreements; Transparency; Corruption; Doha Round
\end{abstract}

\section{Introduction}

With the conclusion of the Uruguay Round and the creation of the World Trade Organization (WTO), multilateral disciplines applying to all WTO members were established in many areas. One substantial exception is in government procurement, where the principles of nondiscrimination have only been accepted on a voluntary, plurilateral basis. Developing countries have been subject to substantial pressure to agree

* Corresponding author. World Bank, 1818 H Street NW, Washington, DC 20433, USA. Tel.: +1-202-4731185; fax: +1-202-522-1159.

E-mail address: bhoekman@worldbank.org (B.M. Hoekman). 
to multilateral disciplines limiting their ability to discriminate in favor of domestic firms when allocating state contracts. Their vigorous resistance to such pressure led a number of WTO members in the late 1990 s to propose that multilateral efforts be confined to attaining agreement on improving transparency in this area. ${ }^{1}$ At the December 1996 WTO Ministerial meeting in Singapore, it was agreed to establish a Working Group with the mandate to study transparency in government procurement practices and develop "elements for inclusion in an appropriate agreement" (WTO, 1996, p. 6). ${ }^{2}$ Having said that, at this time, members of the WTO have yet to agree whether, when and on what terms negotiations on this subject will begin.

Given that the WTO is a forum to negotiate and enforce commitments to improve access to national markets, one important motivation for pursuing transparency in this forum is to enhance the capacity of foreign suppliers to contest procurement markets. In this paper, we investigate the extent to which improving transparency enhances market access. We also examine the likely impact on national welfare of alternative multilateral disciplines on government procurement policies, allowing an assessment of whether reforms that enhance welfare also improve market access, and visa versa. This two-part evaluation is important, as traditionally, the formula for successful trade reform under the WTO umbrella has involved initiatives that enhance national welfare through improving market access. ${ }^{3}$

Although our analysis is largely motivated by developments at the WTO, the findings also apply to regional efforts to agree on common rules for procurement practices. Procurement disciplines are, for example, on the agenda of the Free Trade Area of the Americas (FTAA) initiative, and will also figure in future efforts to expand the coverage of Euro-Mediterranean Partnership Agreements. More generally, the analysis developed here can be applied to situations where one group of potential purchasers decides to discriminate against a class of sellers on the basis of an observable characteristic that is not directly related to the product itself, such as location of the production facility of a seller. As such, our analysis may shed light on the effects of consumer and investor boycotts and not just the behavior of state-procuring entities.

Like others, we analyze the impact of state procurement discrimination against foreign firms in a partial equilibrium setting with perfect competition. Unlike earlier studies, however, we are not only interested in the short-run consequences of such discrimination but in the long-run effects also. This enables us to examine whether the effects of procurement discrimination are sensitive to the ease of firm entry and exit which, in turn,

1 The United States has played a leading role in this connection. U.S. legislation requires the United States Trade Representative (USTR) to monitor foreign procurement policies that deny access to markets for American goods and services, and procurement policies figure prominently in USTR's annual Foreign Trade Barriers Report. The Clinton Administration made public procurement a priority trade policy issue, linking this to the broader issue of corruption. "This Administration is determined to...push initiatives to clean up government procurement practices around the world" (Financial Times, May 1, 1995, p. 5). In April 1996, largely at the insistence of the US, OECD members agreed not to allow firms to write off bribes against tax obligations (Oxford Analytica, April 18, 1996).

2 For an analysis of the origins of this Working Group, and its relationship to the Uruguay Round Agreement on Government Procurement (GPA), and the likely consequences of strengthening transparency provisions in the GPA, see Arrowsmith (1997).

3 As is the case in the small open economy that lowers import tariffs as part of a multilateral trade agreement. 
are influenced partly by a nation's competition laws and policies towards foreign direct investment.

First, we confirm the long-standing result of Baldwin and Richardson (1972) that, when government demand is initially more than total domestic firms' supply, the imposition of a ban on foreign sourcing reduces national welfare and market access in the short run and results in positive profits for domestic firms. Second, we allow for unimpeded entry. The positive profits earned in the short run encourage the establishment of new firms which, in turn, drive prices down and eventually eliminate the profits of the incumbent firms. Whether prices fall back to the levels observed before the discrimination occurred depends on the slope of the long-run industry supply function. When that function is horizontal-a necessary condition for which is that the prices of factors of production are unaffected by the size of the industry ${ }^{4}$ - then procurement discrimination does not affect prices in long run. ${ }^{5}$ The principal long-run effect of such discrimination is on the size of the domestic industry, the output of which is determined by government demand.

Next, we turn to the effects of nontransparent procurement practices. We motivate our analysis by the findings of empirical studies of the effects of nontransparency on the composition of government expenditures and on the willingness of firms to supply state contracts. We find that improving transparency has no clear-cut implication for market access, while, for a given distribution of government expenditure, prices fall. Transparency reform need not improve market access and welfare simultaneously - in contrast to what is often the case with other reforms inspired by trade agreements (such as lowering tariffs by small open economies).

The paper is organized as follows. After a brief discussion on the possible rationales for discrimination (Section 2), we analyze the impact of the most severe form of discrimination - a ban on government purchases from foreign suppliers (Section 3). Then, we analyze the impact of a less extreme form of discrimination, so-called price preference polices (Section 4). These analyses use a straightforward partial equilibrium framework, which we extend in Section 5 to include different configurations for firms' costs. In Section 6, we analyze instances where purchasers either have a strong (rational) preference for being in close geographic proximity to suppliers, or operate in markets where products are nontradable (such as services). The effect on national welfare and market access of nontransparent procurement regimes is examined in Section 7. Conclusions are offered in Section 8 .

\section{Motives for and effects of discrimination in procurement}

The rationales for discrimination in procurement vary but in most instances revolve around industrial policy goals, national security considerations, or other noneconomic

\footnotetext{
4 These assumptions are standard to most partial equilibrium treatments of perfectly competitive markets in the long run.

5 So as to avoid confusion, throughout this paper, statements about the effects of procurement discrimination on long-run prices refer only to a comparison of one long-run equilibrium with another long-run equilibrium-and should not be taken as statements about the path taken by prices between those equilibria.
} 
objectives. ${ }^{6}$ The latter include policies that reserve certain types (or a certain share) of contracts for businesses owned by minorities, for firms located in certain geographic regions, or for small and medium-sized enterprises. From a normative perspective, of course, a key question is whether discrimination in procurement is an efficient way of attaining any underlying policy objective. Efficiency is important in this policy area, as it is often claimed that an overarching goal of procurement policies is 'value for money'. 7

In the last 25 years, a small literature has developed focusing on the effects of international discrimination in procurement. Much of this literature considers procurement discrimination in perfectly competitive markets and, in partial equilibrium settings, typically finds no efficiency rationale for discrimination. ${ }^{8}$ In markets characterized by imperfect competition and a small number of firms, discriminating against foreign bidders may also be inefficient. However, with bidding in a small numbers setting, McAfee and McMillan (1989) showed that discrimination may increase national welfare if domestic firms have a cost disadvantage in producing the goods to be procured and only a limited number of firms (foreign and domestic) bid for the contract. A policy that gives preferences to domestic firms reduces the effective competition they face from foreign firms and so induces domestic firms to raise their bids. In contrast, foreign firms respond by lowering their (prepreference-inflated) bids. If the probability of a low-cost foreign firm winning the contract is large enough, this can result in a reduction in the government's expected procurement costs. Here, price preferences effectively shift profits towards domestic firms while potentially reducing government outlays. Even if the cost structures of domestic and foreign firms are identical and account is taken of the social cost of distortionary taxation, discrimination may be optimal simply because foreign firms' profits do not enter into domestic welfare (Branco, 1994; Vagstad, 1995). In the small-numbers context assumed by these models, prices exceed marginal costs, so that shifting demand to domestic firms may also reduce price-cost margins as domestic output expands (Chen, 1995).

Rationales for preferences toward domestic suppliers can be found in other settings as well. Even if there are many potential suppliers, discrimination may be beneficial to the procuring government if the products are intangible or if monitoring contractors and enforcing compliance are costly. In such situations, by paying quasi rents to contractors, procuring agencies can use the threat of losing repeat business to increase the likelihood

\footnotetext{
6 For example, a government may be concerned to preserve a minimum level of production capacity in a defense-related industry because of adjustment costs (Mayer, 1977) or because of learning effects (Arad and Hillman, 1979), should imports become unavailable and future domestic production be required. Mayer proposes a tariff or production subsidy to sustain domestic production but government procurement policy would have the same effect.

7 Having said that, it is not difficult to conceive of models where a government buyer with market power could purchase goods at prices below those in a perfectly competitive market and distort the allocation of resources.

8 In addition to the seminal analyses of Baldwin (1970) and Baldwin and Richardson (1972), relevant contributions that have assumed competitive markets include Lowinger (1976), Herander and Schwartz (1982), Joson (1985), and Kim (1994). Miyagiwa (1991), Branco (1994, 1999), Laffont and Tirole (1993), and Trionfetti (2000) extend the analysis to consider imperfect competition.
} 
of better performance (Laffont and Tirole, 1991; Rotemberg, 1993). ${ }^{9}$ Moreover, geographic proximity may be a precondition for effectively contesting procurement markets-for some products, in particular, services, which in essence, are nontradable. Problems of asymmetric information and contract compliance may imply that entities can economize on monitoring costs by choosing suppliers that are located within their jurisdictions (Breton and Salmon, 1995). In turn, this will make it more difficult for foreign firms to successfully bid for contracts, even if the goods or services involved are tradable. If cross-border trade is frustrated, attention turns to whether there are barriers to entry through establishment (including barriers to foreign direct investments) and to how procuring governments decide whether suppliers are local "enough". An important question, then, is the extent to which the impact of procurement policy depends on the government's stance towards the degree of domestic and foreign competition, a point developed further below.

Although there are a variety of situations under which discriminatory procurement can, in principle, enhance national welfare by lowering procurement costs, little is known about whether actual procurement discrimination has this effect. Even in the case where there are significant differences in production costs between domestic and foreign firms and only a small number of potential suppliers, simulation studies suggest that welfare gains are likely to be modest at best. Greater profits of domestic firms will tend to be offset by increased average prices paid by public entities, resulting in at most, small welfare gains (Deltas and Evenett, 1997). Worse still, small deviations from the optimal policy can actually reduce welfare. And given that the optimal policy in each situation will depend on parameters that are unlikely to be observed by policymakers (such as the distribution of the bidders' costs and the expectations that each bidder has about each other bidder's actions), these findings suggest that in practice, procurement favoritism is likely to be more costly than a policy of nondiscrimination. ${ }^{10}$

In assessing the implications for the multilateral trading system, we are interested in the effect of procurement policies on market access as well as national welfare. Given the long history of bargaining over market access in the GATT/WTO, our analysis will consider the effects of discrimination against foreign firms by state buyers on market access, as proxied by the quantity of imports. If these effects are small, then a nation's exporters are likely to perceive few benefits from negotiating a multilateral agreement on procurement. Consequently, such an agreement will do little to mobilize domestic support for a package of multilateral trade reforms, providing little counterbalance to the opponents of reform. The extent of domestic political support for a welfare-improving trade agreement will depend in large part on its perceived impact on foreign market access.

\footnotetext{
9 Of course, this is not necessarily the optimal instrument. Naegelen and Mougeot (1998) show that alternative instruments, such as cost targets, can be more efficient. Governments may also want to consider dual sourcing in this situation: see, for example, McGuire and Riordan (1995).

10 Most of the literature analyzing discrimination is static with technologies and market structures taken as given. To the best of our knowledge, dynamic aspects have only been investigated in Branco (1999), who shows that discrimination in favor of higher cost domestic firms can enhance their incentives to become more efficient, providing a firmer foundation for interventionist policy in contexts characterized by asymmetric information and imperfect competition. Further research is required in order to explore the robustness of these findings.
} 


\section{The effect of a ban on government purchases from foreign suppliers}

In an influential paper, Baldwin and Richardson (1972) analyzed the effect on imports, prices, and national welfare of a ban on government purchases of foreign suppliers in a partial equilibrium perfectly competitive framework. ${ }^{11}$ They conclude that in the short run, a procurement ban only has an effect on domestic prices, net imports, and national welfare when government demand for the product is greater than domestic supply (at free trade prices). We show below that, in the case of a small open economy, once allowance is made for entry by new firms, a procurement ban may not have a long-run effect on prices. ${ }^{12}$

Our focus on partial equilibrium models can be justified on the grounds that, once one moves beyond the stylized two-good model to a world of many goods, changes in government sourcing patterns for a single good across foreign and domestic suppliers need not affect national factor prices. ${ }^{13}$ The focus on perfectly competitive markets is justified in part by empirical studies that suggest that price-cost markups tend to fall rapidly towards competitive levels once the number of firms in a industry reaches as few as five (Bresnahan and Reiss, 1991). Thus, in many situations, procuring entities are able to source from a large number of firms with little or no market power.

We use a standard framework for analyzing perfect competition in the short run and in the long run, where $P_{\mathrm{W}}$ is the world price of the good; $P_{\mathrm{C}}$ is the unit price paid by the domestic consumer; $P_{\mathrm{G}}$ is the unit price paid by the domestic government; $D_{\mathrm{G}}(p)$ is the demand schedule of the domestic government; $D_{\mathrm{T}}(p)$ is the total domestic demand schedule and includes the demand from the domestic private sector as well as that of the domestic government; $S_{\mathrm{H}}(p)$ is the short-run supply schedule of the domestic industry; $\operatorname{LS}_{\mathrm{H}}(p)$ is the long-run domestic supply curve; ATC and MC are the average total and marginal cost schedules of the representative firm in the domestic industry, respectively; and $\partial$ is the short-run profit of the representative domestic firm. Each domestic firm has a U-shaped average cost curve that reaches a minimum at $C^{*}$. There is assumed to be free entry and exit in the long run. In the short run, the number of firms in the domestic industry is fixed. We also assume that the country is small (a price taker on world markets) so that a reduction in imports does not affect the terms of trade.

As a point of departure, we assume that there is free trade. In the absence of a ban on government procurement from foreign firms, the initial long-run equilibrium is portrayed in Fig. 1. Free entry ensures that profits are zero in the long run, and that $P_{\mathrm{W}}=C^{*}$. Free trade ensures that domestic consumers and the domestic governments pay the world price, $P_{\mathrm{W}}=P_{\mathrm{C}}=P_{\mathrm{G}}$. Note that, in this figure, at the initial equilibrium price $P_{\mathrm{W}}$, domestic industry output is greater than the government's purchases but is less than the total domestic

\footnotetext{
11 See also Herander and Schwartz (1982) and Deardorff and Stern (1998).

12 Recall that throughout this paper, statements about the effects of procurement discrimination on long-run prices refer only to a comparison of one long-run equilibrium with another long-run equilibrium — and should not be taken as statements about the path taken by prices between those equilibria.

13 In a two-good, two-country model, it is straightforward to show that shifts in government demand for a good towards domestic firms can generate general equilibrium effects. Indeed, in cases when government demand for tradables is large in the appropriate sense, such two-by-two models may well provide the basis for useful policy implications.
} 
FIRM

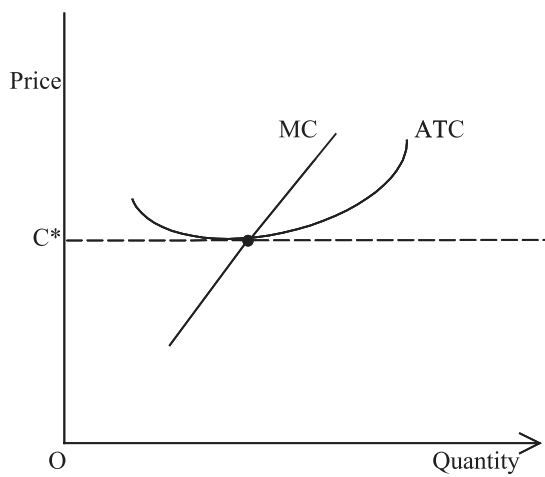

INDUSTRY

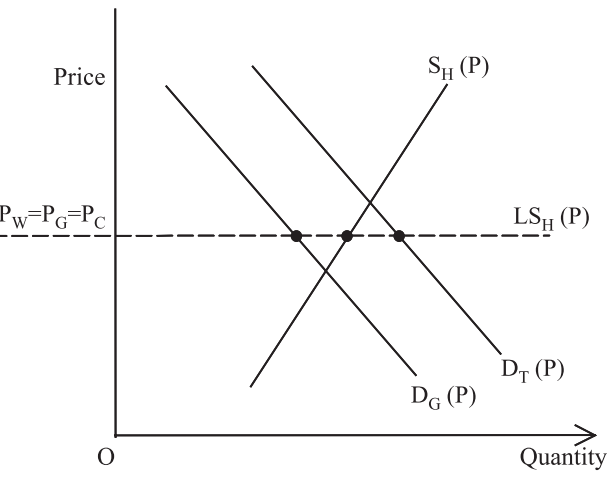

Fig. 1. Procurement ban, government demand less than domestic supply.

demand. In this case, imposing a ban on procurement from foreign suppliers has no effect on equilibrium prices, the quantity of imports, and the quantity produced by domestic firms. All foreign producers that previously supplied the government can find a domestic consumer to supply at world prices; domestic consumers that are abandoned by domestic firms, which now supply the government, can buy from foreign suppliers. Each domestic supplier is unable to raise the price charged by the government, as other domestic suppliers are willing to step in at the existing world price.

Fig. 2 portrays the case when government demand exceeds domestic supply at free trade prices. A ban on foreign procurement now results in a higher price, $P_{\mathrm{G}}$, paid by the government. Because $P_{\mathrm{G}}>P_{\mathrm{W}}$, total government purchases fall, domestic output rises, and the representative domestic firm makes positive profits. Domestic private sector consumers can still buy from abroad, and do so as foreign producers supply the good at a lower price than domestic firms. Total imports fall from $A C$ to $B C$, and so the procurement ban is

\section{FIRM}

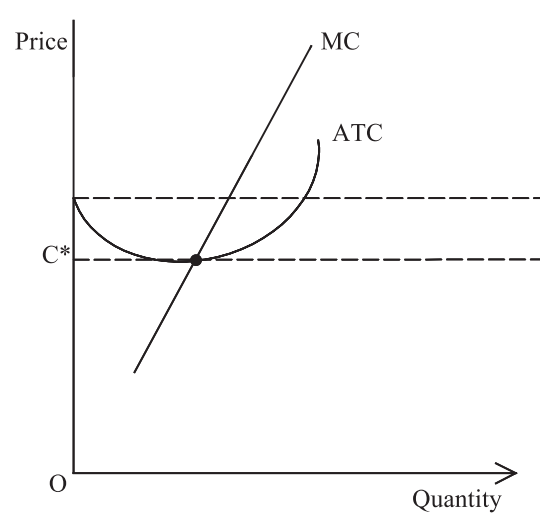

INDUSTRY

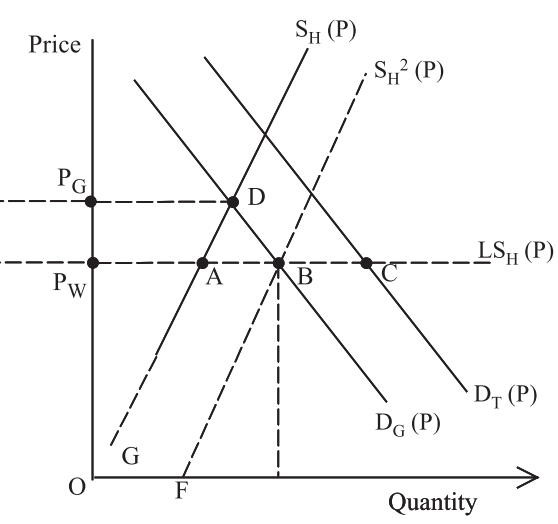

Fig. 2. Procurement ban, government demand exceeds domestic supply. 
said to reduce market access. There is also an adverse impact on national welfare with a deadweight loss equal to area $A D B$. Because domestic private sector consumer choices are unaffected by the foreign procurement ban, their consumer surplus does not change. ${ }^{14} \mathrm{We}$ have, therefore, replicated the principal findings of Baldwin and Richardson (1972).

We now consider the long-run effects of procurement discrimination. First, we allow for the free entry of firms. This does not alter the analysis in Fig. 1, as the imposition of a procurement ban does not change the profitability of domestic firms. In contrast, in the case portrayed in Fig. 2, a procurement ban raises the profits of domestic firms in the short run. New domestic firms therefore enter the industry, shifting the short-run domestic industry supply curve to the right, and prices fall until profits are eliminated at $P_{\mathrm{G}}=P_{\mathrm{W}}$. This result obtains, partly because of the assumptions that foreign and domestic firms have identical minimum long-run average total costs, ${ }^{15}$ that there are no other trade restrictions, and that firms' cost functions do not change as the industry expands, so that the long-run domestic industry supply curve $\operatorname{LS}_{\mathrm{H}}(p)$ is horizontal. Domestic sales to the government are then given by the quantity at point $B$ in the long-run equilibrium. Under free entry, therefore, a procurement ban only distorts prices in the short run.

In sum, the welfare consequences of a ban on state procurement from foreign firms depend not only on the relative size of government demand and domestic industry output at the free trade prices, but also on the ease of entry which, in turn, depends on a number of factors including a nation's competition policies. The long-run effects of imposing a procurement ban are summarized in Table $1 .^{16}$

The consequence of removing a foreign procurement ban is also sensitive to assumptions about the ease of entry. Suppose the market is in long-run equilibrium and the ban is eliminated. In the case of Fig. 1, nothing changes: the government need no longer buy from domestic firms, but has no incentive to switch to foreign firms as $P_{\mathrm{G}}=P_{\mathrm{W}}$. In the case of Fig. 2, with no entry allowed, the preliberalization long-run equilibrium is point $D$, where $P_{\mathrm{G}}>P_{\mathrm{W}}$. Absent entry, removing the procurement ban would shift the equilibrium back to point $A$, reducing the domestic industry's output, eliminating the rents and the consumption distortion and increasing imports from $B C$ to $A C$. Here, procurement

14 However, consumers (or rather taxpayers) do bear the cost of any deadweight losses associated with the need to raise revenues through distortionary taxation. Of course, whether the price increases induced by the procurement ban results in greater total government spending on the good in question depends on the own price elasticity of demand of that good.

15 While one might object to this assumption, the obvious alternatives to it have some unappealing consequences when considering long-run equilibria. If domestic and foreign firms have different minimum longrun average total costs, in the absence of trade barriers, it would be impossible for both types of firms to potentially supply the domestic government in the initial long-run equilibrium. If in the initial long-run equilibrium the foreign firms had lower costs than domestic firms, domestic firms would not supply domestic consumers - and so would have had no sales. (That is, there would have been no domestic industry to shift government contracts towards.) The assumption of identical minimum average total costs can of course be relaxed even in the absence of trade policy to allow for a foreign cost advantage. This could reflect an international friction (such as transportation costs) that exactly closes the gap between the minimum long-run average costs of the foreign and domestic firms.

16 One might question the assumption of constant industry costs that underpins the horizontal industry supply curve. We discuss the increasing industry cost case (the case of an upward sloping long-run supply schedule) in Section 5 . 
Table 1

The effect on long-run equilibrium outcomes of a procurement ban

\begin{tabular}{llll}
\hline Variable & At initial free trade prices, $P_{\mathrm{W}}$ & \\
\cline { 2 - 4 } & $D_{\mathrm{G}}\left(P_{\mathrm{W}}\right)<S_{\mathrm{H}}\left(P_{\mathrm{W}}\right)$ & $D_{\mathrm{G}}\left(P_{\mathrm{W}}\right)>S_{\mathrm{H}}\left(P_{\mathrm{W}}\right)$ & Free entry \\
\cline { 2 - 4 } & & No free entry & 0 \\
Price & 0 & + & + \\
Qumestic industry output & 0 & - & - \\
\hline
\end{tabular}

0 : no change from initial preban long-run equilibrium; -: decline; +: increase.

liberalization would increase imports, eliminate the distortions created by the ban, and so restore national welfare to its preban levels. However, if entry is costless and point $B$ represents the domestic firm's sales to the government in the long-run equilibrium before liberalization, removal of the ban does not alter the long-run equilibrium price, as every domestic supplier can find a buyer at this price, and every domestic purchaser can find a domestic or foreign supplier. No one has an incentive to alter their plans; thus, removal of the procurement ban will not change the level of imports or the output of the domestic industry.

This finding of irreversibility is not due to the traditional sense associated with models with hysteresis - that is, neither the exogenous policy change considered here nor the firms' responses to that change have altered any of the fundamental parameters of the model (such as the cost functions or technology of the firms). Rather, the irreversibility result is an implication of the long-run equilibrium of the standard perfectly competitive model employed here. Specifically, if both the foreign and domestic firms have the same U-shaped cost functions and have positive levels of sales, then the zero profit condition implies that all firms charge the same price, $C^{*}$. The latter implies that, although the elimination of the procurement ban allows the state to buy from foreign firms, the government would have no incentive to do so.

These findings differ from those that follow from traditional analyses of border barriers, such as tariffs and quotas. The latter place considerable weight on the general equilibrium effects of a sector's expansion in response to the imposition of a trade barrier. To the extent that such effects result in an upward sloping long-run industry supply function, this case is considered in Section 5.

\section{The effects of price preference policies}

In practice, rather than ban all purchases from foreign firms outright, governments often employ price preferences to discriminate against foreign suppliers. ${ }^{17}$ That is, the government inflates the actual supply price of foreign suppliers by $\rho \%$, where $\rho>0$ is the margin of preference. If a foreign firm's 'preference-inflated' price is below that the price at which domestic firms are willing to supply, then the government purchases from

\footnotetext{
17 Examples include the $15 \%$ price preference allowed under World Bank procurement rules and the $10 \%$ price preference granted to minority-owned businesses in the US.
} 


\section{FIRM}

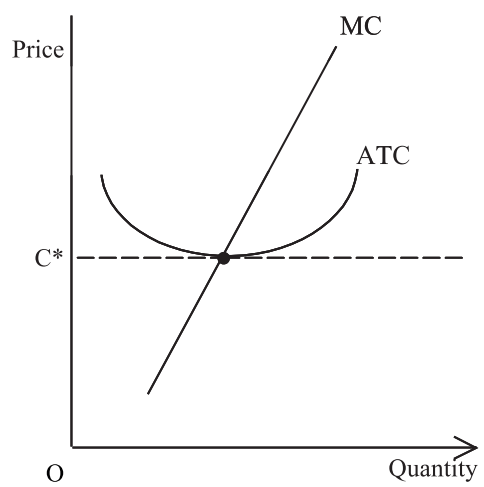

INDUSTRY

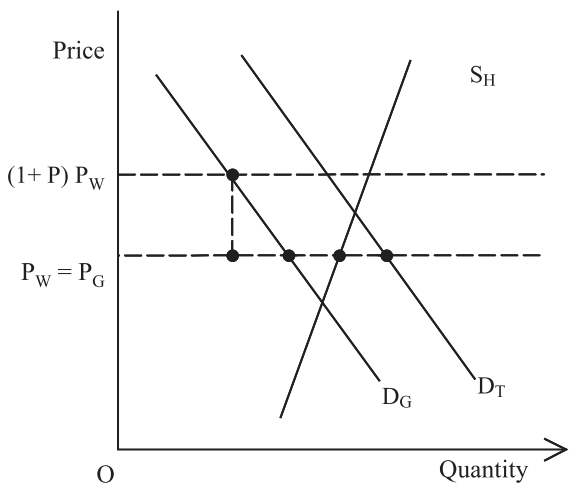

Fig. 3. Price preference, government demand less than domestic supply.

the foreign seller at the latter's actual supply price (and not at the preference-inflated price). Otherwise, the government buys from a domestic supplier.

The analogue to Fig. 1 is in Fig. 3: in this case, at free trade prices, the quantity demanded by the government is less than or equal to the quantity supplied by the domestic industry. Irrespective of the value of $\rho$, the price preference policy results in the same reallocation of sales between firms that occurred under a procurement ban in the last section. Government purchasers compare the supply price of foreign suppliers $\left[(1+\rho) P_{\mathrm{W}}\right]$ with those of domestic suppliers $\left(P_{\mathrm{W}}\right)$, and decide to source solely from domestic firms. Again, switching their purchases to domestic suppliers has no effect on prices, imports, domestic output, and national welfare, because in this case, any foreign supplier that was previously supplying the government can now find a domestic private customer to sell at the original price $P_{\mathrm{W}}$.

FIRM

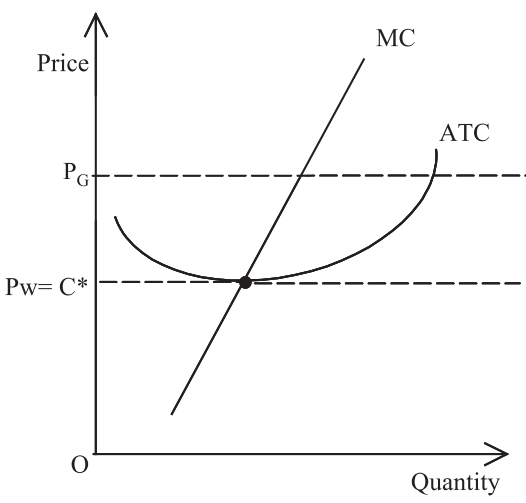

INDUSTRY

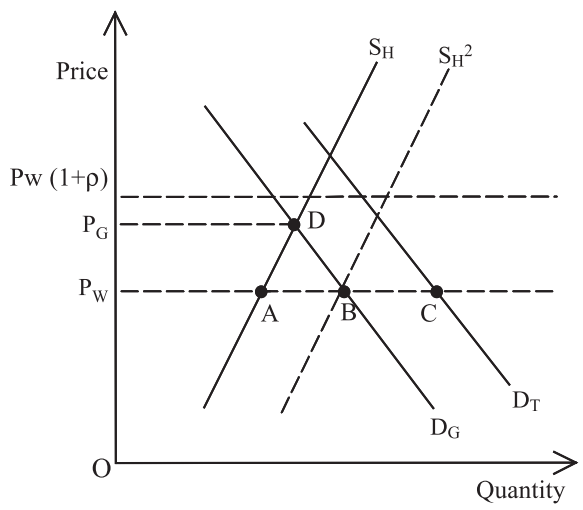

Fig. 4. Price preference, government demand exceeds domestic supply (case 1). 
FIRM

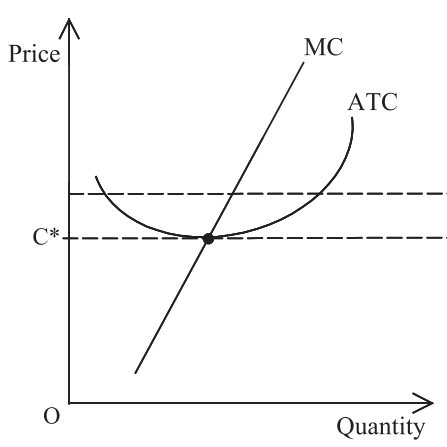

INDUSTRY

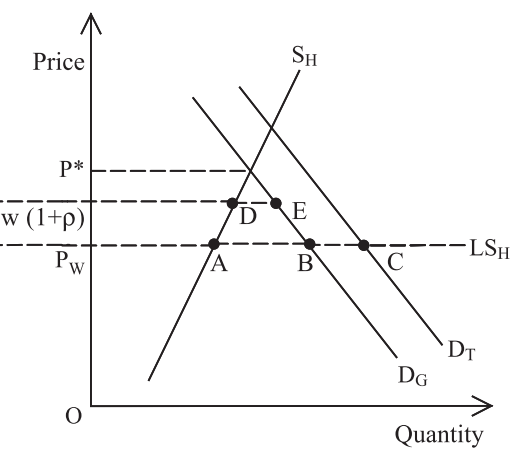

Fig. 5. Price preference, government demand exceeds domestic supply (case 2).

When government demand exceeds domestic supply at free trade prices, two cases must be distinguished. The first case is where the margin of price preference $\rho$ is greater than the percentage increase in price that would result if only domestic suppliers were allowed to sell to the domestic government (see Fig. 4). Starting from the original long-run equilibrium at point $A$, the preference policy effectively "prices" the foreign suppliers out of the market because their supply price to the government rises to $P_{\mathrm{W}}(1+\rho)$. Here, government demand can only be met by domestic suppliers at a higher price $P_{\mathrm{G}}$. In the absence of entry, point $D$ is both the short- and long-run equilibrium, and similar to a procurement ban, the price preference policy creates both a long-run consumption and resource allocation distortion. Here, removal of the price preference policy would shift the equilibrium back to $A$, eliminating both distortions and restoring the "lost" market access.

However, if entry can take place in the long run, any rents created by the preference policy in the short run will attract domestic firms into the industry. Analogous to Fig. 2, with a horizontal long-run supply curve $\mathrm{LS}_{\mathrm{H}}$, a long-run equilibrium prevails where domestic firms supply the government the quantity of goods associated with point $B$ and there is no distortion to long-run resource misallocation. Moreover, the subsequent elimination of the preference policy would have no impact on prices, domestic output, net imports, and welfare. With free entry, the reduction in imports (from $A B$ to $B C$ ) caused by imposing a price preference policy cannot be reversed by its removal.

The second case is portrayed in Fig. 5: here, the margin of preference $\rho$ is less than the percentage increase in price that would result if only domestic suppliers were allowed to sell to the domestic government. ${ }^{18}$ Thus, $\rho$ is low enough so as not to price foreign suppliers entirely out of the market. Any domestic firm that attempts to price above $P_{\mathrm{W}}(1+\rho)$ will find itself with no customers, state or private. Consequently, in the short run, prices paid by the state to domestic suppliers rise to $P_{\mathrm{W}}(1+\rho)$, and the government still

\footnotetext{
18 In the limiting case-where the price preference $\rho$ is equal to the percentage increase in price that would result if only domestic suppliers were allowed to sell to the domestic government - the situation is identical to that of a complete procurement ban on sourcing from foreign firms; whose effects were analyzed in the last section.
} 
Table 2

The effect of price preferences on short-run and long-run equilibrium outcomes

\begin{tabular}{|c|c|c|c|c|}
\hline \multirow[t]{4}{*}{ Variable } & \multicolumn{4}{|l|}{ At initial free trade prices } \\
\hline & \multirow{3}{*}{$\frac{D_{\mathrm{G}}<S_{\mathrm{H}}}{\text { Short- and long-run impact }}$} & \multicolumn{3}{|l|}{$D_{\mathrm{G}}>S_{\mathrm{H}}$} \\
\hline & & \multirow[t]{2}{*}{ Short-run impact } & \multicolumn{2}{|c|}{ Long-run impact } \\
\hline & & & No entry & Free entry \\
\hline Price & 0 & + & + & 0 \\
\hline Domestic industry output & 0 & + & + & + \\
\hline Quantity imported & 0 & - & - & - \\
\hline
\end{tabular}

0: no change from the initial long-run equilibrium without price preferences; - : decline; +: increase.

imports some foreign goods (equal to quantity $D E$ ) at the lower price of $P_{\mathrm{W}}$. The price preference creates rents for incumbent domestic firms, as well as consumption and resource allocation distortions. Without entry, the long-run equilibrium remains at point $D$. Elimination of the preference policy would in the no-entry case shift the long-run equilibrium from point $D$ back to point $A$, increasing national welfare and imports.

Allowing for entry in this case (Fig. 5) has some new implications. Domestic firms will enter this market so long as the price paid by the state exceeds $C^{*}$ and rents are being earned; that is, until the prices paid by the government fall back to their original level, $P_{\mathrm{W}}$ (which equals $C^{*}$ ). With free entry, therefore, in the long run, there is no price premium received by the domestic firms supplying the government. In the new long-run equilibrium, the domestic firms' total sales are given by the quantity associated with point $B$ on the long-run supply curve $\mathrm{LS}_{\mathrm{H}}$. However, this expansion of domestic output reduces longrun equilibrium imports to zero. Thus, price preference policies need not eliminate imports in the short run (as a foreign procurement ban would) but, with free entry, such policies can eliminate imports in the long run. This implies that even a small price preference can create a large long-run increase in industry output and a corresponding reduction in imports.

The consequences of a price preference policy are summarized in Table 2.

\section{Increasing long-run industry costs}

The results obtained in Sections 3 and 4 are sensitive to the assumption that the longrun supply curve is horizontal. ${ }^{19}$ The consequences of relaxing this assumption are straightforward: entry will still occur after a procurement ban is imposed, but this will not drive prices for the government back down to $P_{\mathrm{W}}$. In the case of Fig. 2, for example, the long-run equilibrium price paid by the government will be at the point on the line segment $D B$ where this curve intersects with the (now upward sloping) long-run industry

\footnotetext{
19 One reason that this assumption may not hold is if factor prices increase as industry output expands because factors are specific. More generally, it is an empirical matter whether an industry has an increasing longrun supply curve or a horizontal supply curve.
} 
supply curve. The implication is that in the long run, the domestic market for the product concerned becomes segmented as government continues to pay a price that exceeds $P_{\mathrm{W}}$. Thus, although domestic private consumers remain unaffected, there is a resource allocation distortion. Furthermore, the size of this distortion is smaller when entry is possible compared to the no-entry case; again highlighting the importance of entry barriers in determining the magnitude of any resource misallocation created by procurement discrimination. In terms of market access, if the long-run industry supply curve is upward sloping, removing a binding foreign procurement ban or price preference will result in some domestic firms exiting the industry and imports increasing.

Another interesting point emerges when the long-run industry supply curve is upward sloping: the market segmentation that results from procurement discrimination also creates an incentive for arbitrage. Consider the short-run equilibrium that results from the imposition of a procurement ban in a market where initially, government demand exceeded domestic supply at free trade prices. Here, $P_{\mathrm{G}}>P_{\mathrm{W}}$ and traders will find it profitable to import goods and resell them to the state purchasers. (After all, by assumption, these foreign products are perfect substitutes to the output of domestic firms.) If procurement officials are subject to hard budget constraints and have incentives to minimize costs, they may be inclined to circumvent the ban. The same is true if officials are not solely interested in obtaining value for money. For example, if there is corruption, officials may seek to procure foreign goods at (probably just above) world prices in return for kickbacks from the suppliers. This suggests another channel by which discrimination in procurement can generate incentives for corruption. Moreover, in this case, the incentive to engage in corrupt practices created by procurement discrimination may well mitigate any market access reductions suffered by foreign firms.

\section{Procurement of nontradables, services, and 'proximity' goods}

Much of what is procured by governments is nontradable - including many services. Francois et al. (1997) note that in 1993, purchases by federal, state, and local authorities in the United States exceeded US\$1.4 trillion, equivalent to some 20\% of GDP. Out of this, federal procurement totaled US\$445 billion, of which, 68\% was spent on defense (goods, services, and employee compensation). Of the remaining US\$141 billion, employee compensation comprised 48\%, leaving US\$73 billion. Most of this (US\$59 billion) was used to procure services. After wages, at the state and local level, the largest category of expenditure is construction. Therefore, to a large extent, services are the most significant component of procurement markets.

A difficulty that arises in evaluating discriminatory policies towards the procurement of nontradables is the absence of a world price. Independent of the potential effects of discriminatory procurement regimes, national markets will be segmented and prices will depend, to a large extent, on local factor costs and technologies. However, in the long run, free entry ensures that firms earn zero profits, and that prices are set at minimum average cost. In this case, an assumption of U-shaped cost curves conveniently determines longrun prices. In addition to the earlier notation, we denote $D_{\mathrm{H}}(p)$ as the demand schedule of domestic private consumers for the nontraded good or service. 
FIRM

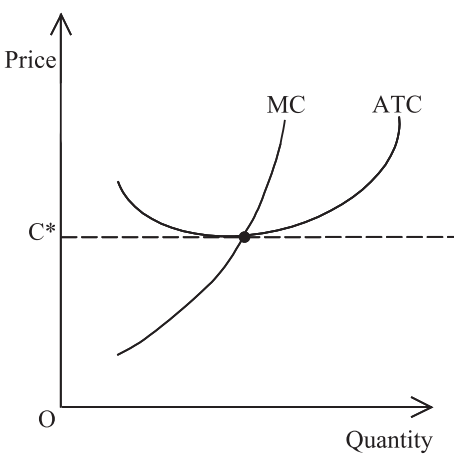

INDUSTRY

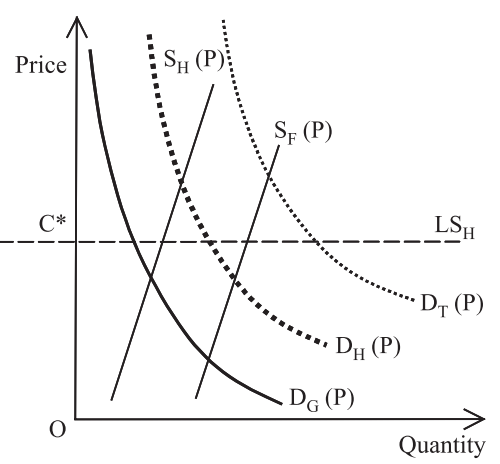

Fig. 6. Nontradables: a ban on purchases from foreign-owned firms when demand is less than domestic supply.

To fix ideas, we consider the effect of a ban on government purchases from subsidiaries of foreign firms that have already established a local presence. ${ }^{20}$ Assume that both domestically owned (or "home") and foreign-owned firms have access to the same technology and confront the same factor prices. Fig. 6 portrays the long-run equilibrium in the absence of the procurement ban: in this case, the prevailing price $C^{*}$ is such that government demand is less than home firms' supply, i.e., $S_{\mathrm{H}}\left(C^{*}\right)>D_{\mathrm{G}}\left(C^{*}\right)$. The imposition of a ban has no effect - it merely reallocates customers to foreign affiliates. ${ }^{21}$

If at the initial long-run equilibrium price $C^{*}$, government demand exceeds home supply (and therefore, some foreign affiliates must be supplying the government initially), a procurement ban effectively segments the market (Fig. 7). With such a ban, home firms will supply the government at price $P^{\mathrm{I}}$ (which is higher than $C^{*}$ ) and foreign subsidiaries are left supplying only the private sector at a lower price $P^{\mathrm{II}}$. (The latter occurs because home private consumers are unwilling to buy all of the output of these subsidiaries at the initial price $C^{*}$.) The short-run effect of imposing a procurement ban is therefore to introduce two consumption and two production distortions. Unlike the tradable goods case, in the short run, a ban on procuring services from foreign subsidiaries raises home private consumers' welfare. This is because the exclusion of foreign subsidiaries from the market to supply the government creates an excess supply that can only be eliminated by lowering prices to the only agents willing to buy these subsidiaries' services; namely, domestic private consumers. The extent of this price fall is constrained, however, by the traditional shutdown condition for firms operating in the short run (that the price charged must equal or exceed the average variable costs of production).

This situation cannot persist in the long run as foreign-owned firms are making losses, and some of these firms will exit until the price paid by home consumers rises to $C^{*}$ and

20 Evenett and Hoekman (2000) discuss services procurement issues, including the treatment of services in the WTO Agreement on Government Procurement in greater depth.

21 In nontradable services markets, the appropriate comparison is between government purchases and home firms supply at free trade prices, not between government purchases and total supply. 
FIRM

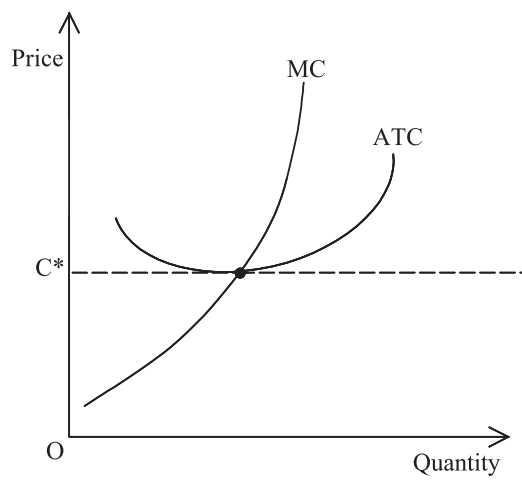

INDUSTRY

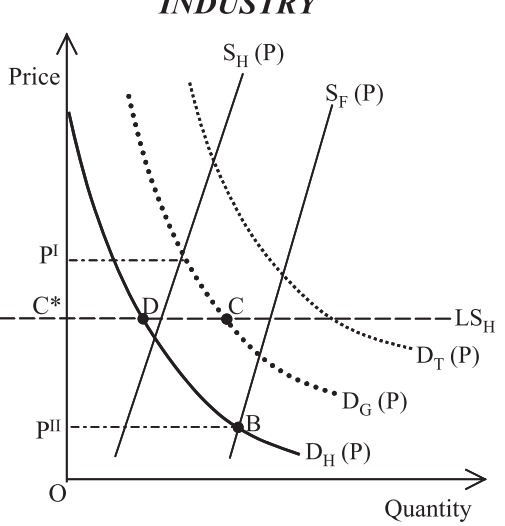

Fig. 7. Nontradables: a ban on purchases from foreign-owned firms when demand exceeds domestic supply.

the remaining foreign subsidiaries break even. In Fig. 7, this implies that the home consumers' demand returns to point $D$ from point $B$. Turning now to the home firms, these firms were making positive profits at the short-run equilibrium price $P^{\mathrm{I}}$. If entry can take place, the effect of the new entrants will be to decrease the price paid by the government until all firms make zero profits (at price $C^{*}$ and government demand at point $C$ ). Thus, the long-run effect of the ban is to increase the number of domestically owned firms and to reduce the number of foreign-owned firms. The minimum level of average costs pins down prices in the long run, and therefore, in the long-run equilibrium with a procurement ban, the state and domestic consumers pay exactly the same price for the services purchased. Moreover, once this new long-run equilibrium is achieved, the removal of the procurement ban would have no effect on equilibrium prices as the state would have no incentive to switch from domestic firms to foreign affiliates in the new long-run equilibrium. Table 3 summarizes our findings for the case of services, which reinforce

Table 3

The effect on long-run equilibrium outcomes of the imposition of a procurement ban from foreign-owned suppliers of nontraded goods and services

\begin{tabular}{|c|c|c|c|c|}
\hline \multirow[t]{3}{*}{ Variable } & \multicolumn{4}{|c|}{ At initial free trade prices $\left(C^{*}\right)$} \\
\hline & \multirow[t]{2}{*}{$D_{\mathrm{G}}\left(C^{*}\right)<S_{\mathrm{H}}\left(C^{*}\right)$} & \multicolumn{3}{|l|}{$D_{\mathrm{G}}\left(C^{*}\right)>S_{\mathrm{H}}\left(C^{*}\right)$} \\
\hline & & $\begin{array}{l}\text { Short run and } \\
\text { long run without } \\
\text { entry or exit }\end{array}$ & $\begin{array}{l}\text { Long run with } \\
\text { exit only }\end{array}$ & $\begin{array}{l}\text { Long run with } \\
\text { entry and exit }\end{array}$ \\
\hline $\begin{array}{l}\text { Price paid by home } \\
\text { consumer }\end{array}$ & 0 & - & 0 & 0 \\
\hline $\begin{array}{l}\text { Price paid by } \\
\text { government }\end{array}$ & 0 & + & + & 0 \\
\hline Home firm's output & 0 & + & + & + \\
\hline $\begin{array}{l}\text { Foreign subsidiaries' } \\
\text { output }\end{array}$ & 0 & - & - & - \\
\hline
\end{tabular}

0: no change from initial preban long-run equilibrium; -: decline; +: increase. 
the importance of entry and exit in determining the long-run effect of discriminatory procurement policies. $^{22}$

\section{Transparency}

The foregoing sections focused on discrimination against foreign firms. In the current WTO context, however, discussions among officials concern measures to improve the transparency of public procurement. A lack of transparency can impede the ability of foreign firms to bid for contracts even if there is no discrimination. Opaque procurement practices may result from either administrative inefficiencies, the absence of hard budget constraints and oversight by the Ministry of Finance, or rent-seeking and corruption. The result can be a substantial loss for the government budget (as contracts will not go to the most efficient supplier). Case studies reveal that excess costs for a project can be in the range of 25-50\% (Rose-Ackerman, 1995a,b; Ades and Di Tella, 1997; Bardhan, 1997).

Analyzing the effects of opaque procurement regimes requires specifying the motives for nontransparency, and its effects (if any) on firms' costs and on the composition of government expenditure. Several cases can be distinguished, the first two of which are straightforward applications of the framework developed in previous sections. The first case considered here refers to a situation where a government has not made the investments necessary for a transparent procurement regime. For example, the government may be unwilling or unable to spend resources on public announcements of intended future purchases. Potential suppliers - both domestic and foreign - may therefore be uncertain of the demand curve facing them and so be reluctant to enter the market. To the extent that acquiring information about demand levels in potential markets requires incurring fixed costs (additional costs per unit supplied), one would expect long-run (short-run) market outcomes to be affected. For example, if informational costs raise the marginal costs of firms (irrespective of location), then, this will (i) shift upward the short-run supply schedules of domestic firms and (ii) the price at which foreign firms compete will rise above the world price. In this case, improved transparency reduces costs, which in turn, lowers prices and enhances national welfare.

The second case does not require administrative inefficiency or lack of administrative capacity. Nontransparency could be motivated by a desire on the part of a state agency to circumvent a nondiscrimination rule, using the unclear procurement procedures to systematically favor domestic firms. If so, implementing a transparent procurement regime (perhaps in response to a WTO agreement on procurement) will have the same effects on market access and national welfare as reducing discrimination; thus, the findings reported in earlier sections apply.

These two cases differ from a third case where the lack of transparency is the result of the self-interest of government officials who derive income from bribes as well as from obtaining value for money for their government agency's purchases. A growing body of evidence reveals that corrupt officials deliberately expand expenditures on goods and

\footnotetext{
22 Note that this analysis can be applied to policies that discriminate across different types of domestic firms, e.g., legislation that grants preferences to small- and medium-sized or minority-owned businesses.
} 


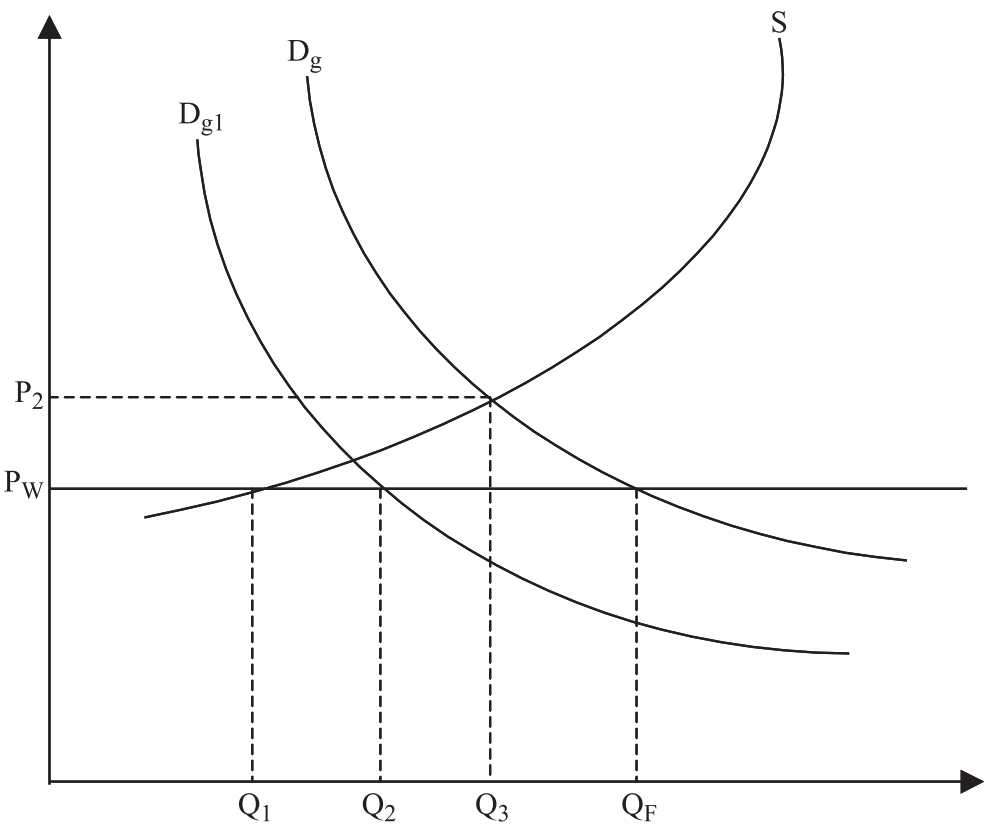

Fig. 8. Impact of greater transparency: demand effects.

projects - such as aircraft and construction — which are highly differentiated and for which there are few, if any, comparable reference prices in world markets (Hines, 1997). Put simply, officials with an interest in personal rents will employ nontransparent procurement procedures to expand government spending where the opportunities for self-enrichment are greatest. ${ }^{23}$ Another consequence of having to pay bribes to bid for government contracts is to reduce the number of domestic bidders. ${ }^{24}$ That is, the result can be thought of as shifting outward the government demand curve for products where there are opportunities for corruption, and at the same time, shifting in the supply curve of firms.

To determine the maximum possible effect on foreign market access of improving the transparency of a procurement regime, assume that initially foreign firms found it so costly to overcome the opaque contracting procedures that none of them willingly supply the domestic government. ${ }^{25}$ Fig. 8 represents the short-run domestic supply and demand curves for a good. With an opaque procurement system, foreigners do not supply anything

23 Further evidence for this argument can be found in Mauro (1998), who finds that spending on education is lower in more corrupt economies and conjectures that the purchase of standard items, such as textbooks and the hiring of teachers, offer fewer opportunities for corruption than more capital-intensive government projects.

24 This is especially likely to drive out small- and medium-sized enterprises (SMEs). Unlike larger firms, SMEs do not have as many resources to devote to dealing with officials and paying bribes. See Tanzi and Davoodi (2002).

25 Of course, this need not be the case as an opaque procurement regime may be deliberately designed so as to extract bribes from foreign firms. However, this is illegal under U.S. law for US-based firms, while recent initiatives in the OECD context have made it more difficult for other OECD-based firms to engage in bribery. 


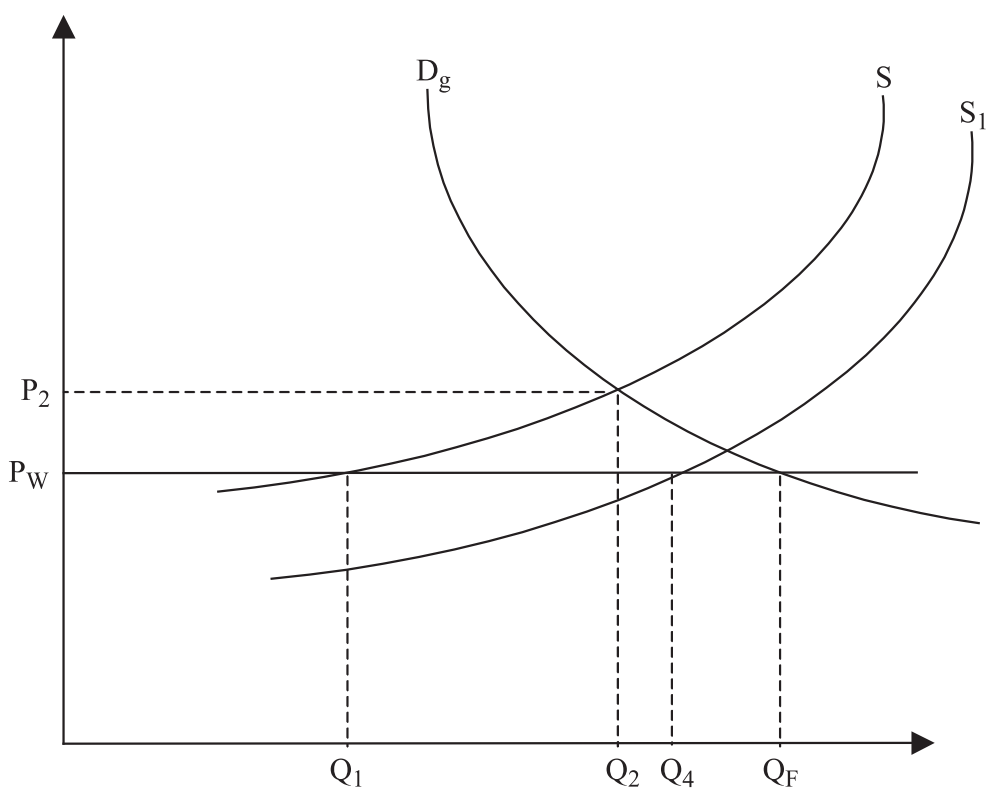

Fig. 9. Impact of greater transparency: supply effects.

to the government and domestic firms sell output $Q_{2}$ at price $P_{2}$ to the state. Now, suppose that, following a multilateral agreement, a transparent procurement procedure is imposed and corruption ceases. This reform has two effects: the first is to reallocate government spending away from goods that were more prone to bribery and the second is to allow foreigners to sell to the government. In terms of Fig. 8, the first effect shifts the government's demand curve from $D_{\mathrm{g}}$ to $D_{\mathrm{g} 1}$. The government takes advantage of its new access to world prices and buys quantity $Q_{3}$, which is less than if the demand curve had remained at $D_{\mathrm{g}}$. The quantity imported rises from zero to $\left(Q_{3}-Q_{1}\right)$. However, the case represented in Fig. 8 is not the only relevant one: if the fall in government demand is large enough so that domestic firms can now entirely supply the government's demand (at world prices), market access may not improve at all. ${ }^{26}$ In fact, it is possible for improvements in transparency to raise welfare without enhancing market access.

Elimination of a nontransparent procurement procedure will have another effect, namely, expanding the number of domestic firms willing to sell to the government. This case is shown in Fig. 9. The starting point is the same as in Fig. 8: in the presence of a nontransparent procurement procedure, the equilibrium price $P_{2}$ prevails and domestic

26 The lower impact on market access of transparency reform may be offset by greater imports of those goods that the government now increases expenditure on. In principle, this latter effect may ensure that transparency reform creates more market access than eliminating a straightforward procurement ban, but the circumstances under which this occurs are restrictive. This is due to the requirement that government demand must end up exceeding domestic firms' supply for imports to increase after the reallocation of government spending towards goods which offered (in the past) fewer opportunities for corruption. This requirement may not be satisfied for all the goods for which government demand expands under a transparent procurement regime. 
firms supply quantity $Q_{2}$. Ignoring the effect of transparency reform on the government's demand curve, such reform results in more domestic firms entering the market (because these firms no longer have to spend time and money on payments to officials), which shifts the domestic supply curve to $S_{1}$. With the government now able to buy at world price $P_{\mathrm{W}}$, domestic firms supply $Q_{4}$ and imports expand to $\left(Q_{\mathrm{F}}-Q_{4}\right)$. For a sufficiently large outward shift of the domestic supply curve, there may be no market access improvement at all. Overall, then, there is no guarantee that improving transparency will increase both welfare and market access simultaneously.

\section{Concluding remarks}

Successful trade policy agreements tend to simultaneously improve market access and national welfare, with the former being the instrument to achieve the latter. Reciprocal reductions in national tariff rates, for example, result by and large in both improved market access and higher levels of national welfare. ${ }^{27}$ While much has been accomplished in reducing many trade barriers over successive multilateral trade negotiations - see Hoekman and Kostecki (2001) — much less has been achieved in trade negotiations on public procurement. Our analysis provides one explanation why: potential international disciplines on procurement policies, whether they relate to transparency or to nondiscrimination, need not to translate into simultaneous improvements in market access and national welfare.

In many circumstances, the effect of discriminatory procurement regimes on national welfare will be limited in magnitude and duration. In the short run, government demand can be "too small" for discrimination to affect market outcomes. However, if the demand of government is initially larger than domestic supply, procurement discrimination will reduce imports and lower national welfare in the short run. The long-run consequences of such discrimination, however, depend critically on other factors, in particular, the extent of barriers to entry and exit. We have demonstrated that, under certain conditions, procurement discrimination can have no effect on long-run equilibrium prices. The latter finding follows from the fact that in the long run, perfectly competitive industry with free entry, prices are determined solely by the minimum average costs (and therefore, not by the presence or absence of discrimination) and equilibrium output is determined by the demand schedule of the government.

The focus of current WTO discussions is on transparency in government procurement practices, not on banning discrimination against foreign suppliers in procurement procedures. We have shown that there is no clear-cut relationship between transparency in procurement and market access, which casts doubt on the support of export interests for a multilateral agreement on transparency practices in state contracting. Even if the quid pro quo for enhanced transparency is in terms of better access to overseas private sector

27 The rationale for reciprocity is a political economy one, the market access mechanism being a way for governments to transfer income towards export sectors, thereby providing them with incentives to support liberalization at home and allowing the governments involved to benefit politically from the market access provided by partner countries (Hillman and Moser, 1996, Hillman et al., 1995). 
markets or in terms of improved WTO rules in other areas, a major question arises as to what pressure a government will feel from abroad to comply with any such multilateral disciplines if nontransparency does not substantially erode foreign market access to state contracts. Only when the latter is affected do foreign firms tend to lobby their governments to bring cases of noncompliance to the WTO's dispute settlement mechanism. Both of these considerations cast doubt on the magnitude of the potential benefits of embedding rules on transparency in government procurement in trade agreements - whether multilateral or regional.

\section{Acknowledgements}

We are very grateful to Arye Hillman, a referee, and Richard Baldwin, Fernando Branco, Aaditya Mattoo, Marcelo Olarreaga, Garry Pursell, David Tarr and participants in seminars and workshops at the World Bank, CEPR, and the Brookings Institution for helpful comments and discussions on earlier versions of this paper. The views expressed are those of the authors and should not be attributed to the World Bank.

\section{References}

Ades, A., Di Tella, R., 1997. National champions and corruption: some unpleasant interventionist arithmetic. Economic Journal 107, 1023-1042.

Arad, R., Hillman, A., 1979. Embargo threat, learning and departure from comparative advantage. Journal of International Economics 9, 265-275.

Arrowsmith, S., 1997. Towards a multilateral agreement on transparency in government procurement. International and Comparative Law Quarterly 47, 793-810.

Baldwin, R., 1970. Nontariff Distortions of International Trade. Brookings Institution, Washington, DC.

Baldwin, R., Richardson, J.D., 1972. Government purchasing policies, other NTBs, and the international monetary crisis. In: English, H., Hay, K. (Eds.), Obstacles to Trade in the Pacific Area. Carleton School of International Affairs, Ottawa.

Bardhan, P., 1997. Corruption and development: a review of issues. Journal of Economic Literature 35, $1320-1346$.

Branco, F., 1994. Favoring domestic firms in procurement contracts. Journal of International Economics 37, $65-80$.

Branco, F., 1999. Procurement favoritism and technology adoption. Discussion Paper 2270, Center for Economic Policy Research, London.

Bresnahan, T., Reiss, P.C., 1991. Entry and competition in concentrated markets. Journal of Political Economy 99, 977-1009.

Breton, A., Salmon, P., 1995. Are discriminatory procurement policies motivated by protectionism? Kyklos 49, 47-68.

Chen, X., 1995. Directing government procurement as an incentive of production. Journal of Economic Integration $10,130-140$.

Deardorff, A., Stern, R., 1998. Measurement of Nontariff Barriers. University of Michigan Press, Ann Arbor.

Deltas, G., Evenett, S., 1997. Quantitative estimates of the effects of preference policies. In: Hoekman, B., Mavroidis, P. (Eds.), Law and Policy in Public Purchasing. University of Michigan Press, Ann Arbor, pp. $73-92$.

Evenett, S., Hoekman, B., 2000. Government procurement of services: assessing the case for multilateral disciplines. In: Sauvé, P., Stern, R. (Eds.), Services 2000: New Directions in Services Trade Liberalization. Brookings Institution, Washington, DC, pp. 143-164. 
Francois, J., Nelson, D., Palmeter, D., 1997. Government procurement in the U.S.: a post-Uruguay round analysis. In: Hoekman, B., Mavroidis, P. (Eds.), Law and Policy in Public Purchasing. University of Michigan Press, Ann Arbor, pp. 105-124.

Herander, M., Schwartz, J.B., 1982. The impact of government price discrimination and its equivalence with the tariff. Weltwirtschaftliches Archiv 118, 525-545.

Hillman, A.L., Moser, P., 1996. Trade liberalization as politically optimal exchange of market access. In: Canzoneri, M., Ethier, W.J., Grilli, V. (Eds.), The New Transatlantic Economy. Cambridge Univ. Press, New York, pp. 295-312.

Hillman, A.L., Long, N., Moser, P., 1995. Modeling reciprocal trade liberalization: the political-economy and national-welfare perspectives. Swiss Journal of Economics and Statistics 131, 503-515.

Hines, J., 1997. Forbidden payment: foreign bribery and American business since 1977. Working Paper No. 5266, National Bureau of Economic Research, Cambridge MA.

Hoekman, B., Kostecki, M., 2001. The Political Economy of the World Trading System: The WTO and Beyond. Oxford Univ. Press, Oxford.

Joson, S., 1985. The GATT agreement on government procurement: Canada and Australia. Australian Economic Papers 20, 76-94.

Kim, I., 1994. Price-preference vs. tariff policies in government procurement auctions. Economics Letters 45, 217-222.

Laffont, J., Tirole, J., 1991. Auction design and favoritism. International Journal of Industrial Organization 9, $9-42$.

Laffont, J., Tirole, J., 1993. A Theory of Incentives in Procurement and Regulation. MIT Press, Cambridge, MA.

Lowinger, T., 1976. Discrimination in government procurement of foreign goods in the US and Western Europe. Southern Economic Journal 42, 451-460.

Mauro, P., 1998. Corruption and the composition of government expenditure. Journal of Public Economics 69, $263-279$.

Mayer, W., 1977. The national defense tariff argument reconsidered. Journal of International Economics 7, $363-377$.

McAfee, R.P., McMillan, J., 1989. Government procurement and international trade. Journal of International Economics 26, 291-308.

McGuire, T., Riordan, M., 1995. Incomplete information and optimal market structure: public purchases from private providers. Journal of Public Economics 56, 125-141.

Miyagiwa, K., 1991. Oligopoly and discriminatory government procurement policy. American Economic Review $81,1320-1328$.

Naegelen, F., Mougeot, M., 1998. Discriminatory public procurement and cost reduction incentives. Journal of Public Economics 67, 349-367.

Rose-Ackerman, S., 1995a. The political economy of corruption. Viewpoint, vol. 74. World Bank, Washington, DC.

Rose-Ackerman, S., 1995b. Redesigning the State to fight corruption. Viewpoint, vol. 75. World Bank, Washington, DC.

Rotemberg, J., 1993. Comment. In: Leitzel, P., Tirole, J. (Eds.), Incentives in Procurement Contracting. Westview Press, Boulder.

Tanzi, V., Davoodi, H., 2002. Corruption, growth, and public finances. In: Abed, G.T., Gupta, S. (Eds.), Governance, Corruption, and Economic Performance. International Monetary Fund, Washington, DC, pp. $197-222$.

Trionfetti, F., 2000. Discriminatory public procurement and international trade. World Economy 23, 57-76.

Vagstad, S., 1995. Promoting fair competition in public procurement. Journal of Public Economics 58, 283 -307.

World Trade Organization, 1996. Singapore Ministerial Declaration. WT/MIN(96)/DEC, WTO, Geneva. 